Volume 31, 2021

http://journals.sfu.ca/dwr

Book Review

\title{
Griffith, J. (2019). Words have a past: The English language, colonialism, and the newspapers of Indian boarding schools. University of Toronto Press.
}

\author{
Shurli Makmillen \\ Claflin University
}

In this well researched and highly readable book, Jane Griffith analyzes six newspapers published in the late $19^{\text {th }}$ early $20^{\text {th }}$ Century by five Indian boarding schools, chosen because they represent the period during which the boarding school system in Canada was becoming systematized, and school newspapers had the widest readership. She analyzes the newspapers as a projection of the public face of Indian boarding schools but also presents these texts as evidence of subversion to their colonial agendas of assimilation, the justification of land theft, and cultural and linguistic genocide. The book's chapters are organized thematically under the broad headings of Time, Space, and Language, key terms which, along with many others, are carefully contextualized and etymologized. The book also addresses literacy in the dominant language, whereby readers can find connections to wider conversations about schooling in other contexts, concerning, especially, English language ideologies.

The introductory chapter, "Bury the Lede," describes how the school newspapers, located across Ontario, Manitoba, Saskatchewan, and British Columbia, operated at a time when their publication was tied to industrial training of young Indigenous people, and before the $20^{\text {th }}$ century shift toward smaller scale mimeographed newsletters whose readership was limited to parents. Although acknowledging "horrific scenes occurred at schools publishing a shiny newspaper each month" (p. 21), Griffith's main focus is not uncovering the untold stories of residential schools; it is, rather, to see what the surface reveals, which includes both institutionally sanctioned and imposed narratives as well as "a veiled poetry of resistance" (p. 2). Ultimate rationales for the existence of school printing 
Volume 31, 2021

http://journals.sfu.ca/dwr

programs are also exposed, especially the settler colonial appropriation of land; in her own words, her book shows how the "newspapers demonstrate that theft began with theory" (p. 21).

Chapter Two, "The Printer's Devil: The Trade of Newspapers," outlines how printing programs were a rare form of workplace training in boarding schools during the period, because, as well as being physically demanding and dangerous work, printing depended on substantial donations of equipment and expertise. Also, there was a more generalized resistance to the idea that Indigenous people should receive this higher-end form of training in the first place, at the expense of farming, blacksmithing, or carpentry. Promoting student literacy through school newspapers was a way of "spreading their assimilative power back to the reserve" (p. 27) and showcasing the work of the schools for subscribers, donors and government overseers far and wide. "The Printer's Devil" alludes to $15^{\text {th }}$ century Black child who was allegedly working as a printing assistant and who was "believed to be an imp of Satan" (Brewer as cited in Griffith, p. 57) and mythically responsible for errors. The name was once applied Gilbert Bear, a graduate of the Battleford School in Saskatchewan who became an exemplary printer, as a way to erase his talents and accomplishments. The thread of Gilbert Bear's story throughout this chapter provides detail to forms of resistance; for example, one account reports that, when asked whether he enjoyed his trip to the Chicago World's Fair showcasing Indigenous progress in Canadian boarding schools (43), Gilbert replied with a flat out "no." This incident was unreported in the school newspaper The Guide, which focused only on his accomplishments.

Chapter Three, "Indigenous Languages did not Disappear: English Language Instruction" reads the school newspapers for evidence of how students "resisted, resignified, and repurposed English in their own ways" (p. 67). In the context of an almost religious fervor surrounding the benefits of the spread of English through Indigenous education, English was also framed as "naturally adopted and preferred" (p. 72) by students. However, the students' letters and essays published in the newspapers are more than just evidence of literacy skills, as the schools would have them. They were also evidence of the importance of family connections, and often revealed perhaps understated difficulties the students were having, such as homesickness and loneliness ("sometimes I am quite lonesome" [p. 84]).

The letters also reveal the persistence of Indigenous languages. One student, for example, wrote to his father that he could "read Indian letter just as well as English letter" and invited him to "write to me in Indian if you like" (p. 84). So, despite the much-discussed English-only mandate, an "Englishand" picture emerges in Griffith's analysis. The adoption of English is, therefore, not only "a gateway, 
Volume 31, 2021

http://journals.sfu.ca/dwr

indeed the gateway, to the newcomers' world" (Hare as cited in Griffiths, p. 88), but also a practice to be adapted and negotiated according to Indigenous interests (e.g., land rights). Though Griffith sees the publication of students' letters as "a particular violation" of students' privacy, the essays and letters provide evidence of both authenticity and creativity in the face of "more predictable storylines of assimilation" (p. 87) in which Indigenous languages were depicted as being "naturally" forgotten. For Griffith, the impact of this linguicide obligates support for Indigenous language resurgence.

Chapter Four brings poetry, theory, testimony, and Indigenous scholarship to bear on "Representations of Indigenous Languages" in the newspapers. Griffith's examples are hard won, given "how school newspapers carefully created an English-only fantasy for readers" (p. 98). Nevertheless, there were sanctioned examples that came in the form of ethnographic salvaging of dying languages, as well as stories of individual teachers who saw the benefits of bilingualism. Griffith puts her Canadian newspapers in the context of the larger mission of Indian boarding schools and interest in Indigenous languages throughout North America. Indeed, much of this chapter is taken up telling a deep-dive story of Shingwuak Home's principal Edward Francis Wilson who traveled extensively across the U.S. visiting schools there and collecting samples of Indigenous languages. Situating his work as a blend of missionary zeal and amateur anthropological interest in languages (p. 113), Griffith suggests this interest in dying languages was a precursor to and a rationale for Indigenous peoples losing rights to land. Though this was not made explicit in the school newspaper Our Forest Children, in a different publication Wilson stated decisively "We want the land. We cannot have Indian hunters annoying our farmers and settlers" (p. 114). Griffith's careful close readings of Wilson's many columns in the newspaper-reading for resistance, we could say-also adds much needed material documentation for what Audra Simpson calls "ethnographic refusal" (as cited in Griffith, p. 127) on the part of the students he interrogated to get his data.

Chapter Five, "Ahead by a Century: Time on Paper," begins the final thematic focus, looking at the way Time was posited in the newspapers as the inevitable agent of Indigenous assimilation, leaving the settler as an innocent bystander or helpful guide in the inexorable march of progress. The passing of time was marked by the newspapers' regular documentation of the deaths of chiefs, "symboliz[ing] the death of Indigenous ways more broadly" (p. 140). Griffith carefully documents what was left out of these obituaries, for example how chiefs engaged in treaty negotiations, how they resisted settler encroachments, or refused Christianity. Their lives were depoliticized for the consumption of the newspapers' readers. The dying chiefs, like the disappearing buffalo, were juxtaposed in the papers with settler efforts at conservation through the formation of national parks, which Griffith points out, 
Volume 31, 2021

http://journals.sfu.ca/dwr

were just another form of a land grab, allowing at the same time for settler "claims to innocence through conservation efforts" and an attitude of "fatalism" (p. 143) toward the inevitability of Indigenous erasure.

The theoretical framework in this chapter draws on the work of Jean O'Brien, who coined the phrase "firsting and lasting" as the "double act of colonialism" (p. 139). Griffith coins her own phrase as "beforing and aftering" to develop an understanding of the articles and images in the papers. Images of before and after were often juxtaposed: two drawings of Kitimat in Na-Na-Kwa in 1909 show a treed and busy waterfront in the first, and a stark denuded supposedly tamed landscape in the second, traditional houses replaced by houses in the "white man's style" and titled "the New Fashion" (p. 145). Photographs of children often came in the same form--to showcase the successful assimilation of the children, but also to accommodate their audience's appetite for the "authentic" Indian. Any Indigenous future was rarely acknowledged in this innocent march of time, with settlers as the "guiltless benefactors" (p. 155). Griffith does detect occasional "cracks in innocence" such as the stark acknowledgment in Our Forest Children that compared the U.S. to the Canadian efforts: "[The Americans] have found that killing the Indians and driving them westward does not pay, the process has been too expensive" (p. 154). A reader cannot help but be struck by the thought that Indigenous children would be type-setting the copy for such proclamations.

Chapter Six, "Anachronism: Reading the Nineteenth Century Today," the longest in the book, begins and ends with the acknowledgement that "thinking about the past is always already about the now" (Griffith, drawing from Million, p. 201). Both the final report of Truth and Reconciliation (TRC) and the Indigenous Residential School Settlement Act loom large in this chapter, whose themes come from the TRC reports. Beginning with ceremony, and its representations in the newspapers, Griffith sees evidence that "ceremony is an era to overcome, participation only permissible as ethnography" (p. 163). Both Potlach and Sundance are criminalized and trivialized, although one student's written piece in Progress speaks of the fun students had participating in the Sundance, adding that "They don't mean any wrong" (p. 163). In newspaper articles about treaty, Griffith is able to trace the shift from Indian control and authorship to government control. Treaty days often got attention because they were opportunities for children to see parents. This reader found the use of third person in articles written by Indian children to be quite jarring (e.g., "The town is full of Indians" [Guide as cited in Griffith, p. 166]), although Griffith acknowledges that “some entries may have been fabricated" (p. 168). Chiefs' speeches were quoted verbatim and with approbation if those chiefs had been treaty signatories, nonetheless treaties were framed as "an event rather than a relationship with 
Volume 31, 2021

http://journals.sfu.ca/dwr

obligations" (p. 170). Predictably, parents were represented as supportive of boarding schools. But the author reveals cracks in this veneer that in many ways expose white pathologies. Rupert's Land school newspaper Aurora, for example, reports parents as having "an unreasonable fondness of having their children with them" (p. 172); parents who resisted boarding schools for their children were seen as negligent or inept (p. 175). On the other hand, with no irony whatsoever, much space is taken up in Kitimat School's newspaper Na-Na-Kwa celebrating the principal George Raney's family "as an inseparable unit" (p. 176). No doubt they did not see the irony when the family professed needing to give up their stay in Kitimat once their child needed to go elsewhere for a decent primary school education.

Schools were subject to oversight-both of the official kind by government inspectors and also occasionally through visits from parents, chiefs, dignitaries, and even tourists-and these visits were written up in the newspapers. Griffith was able to read the newspapers simultaneously with Inspector reports and other documents. For example, a report of Chief Peyasiw-awasis's visit to Battleford school in 1898 did not reveal, as did his letter to Duncan Campbell Scott, his concern about "the deplorable conditions" there (p. 185). Buildings, for example, were often not safe, and fires were a major problem. In the section Fire! Fire! Griffith describes how an article about a fire at Shingwauk Home that was deliberately set by a student framed it as evidence of student criminality, whereas elsewhere such fires, even as early as 1903, were acknowledged as potentially resulting from real grievances (p. 189). In a discussion of newspaper reports about Health, Griffith notes a deflection of attention away from European diseases, poor nutrition, and the substandard conditions at the schools, and on to parents, nature, culture or the inferiority of Indigenous bodies themselves as the locus of the problem. Similarly, reports of Death at the schools were brief, without detail, and cushioned with "happier topics" (p. 196), suggesting to Griffith the students who died while in the care of the schools were not considered "grievable subjects" (p. 198). This wrong is somewhat ameliorated by the TRC devoting one of its six volumes to the topic of residential school deaths, missing children, and unmarked burials.

Chapter Seven, "Layout: Space, Place, and Land," takes full advantage of recent scholarship on colonial geographies enabling Griffith to expose the ways newspapers sanctioned the conversion of "empty" indigenous space into settler place, yet once again providing glimpses into how these assumptions were being resisted and disrupted. The chapter highlights the ultimate purpose of schools, which Griffith again names concisely as land dispossession. 
Volume 31, 2021

http://journals.sfu.ca/dwr

Griffith's concluding chapter is a polemical tour de force, returning to the overarching issues of linguicide and the theft of land, and the role of school newspapers in sanctioning their inevitability. When indigenous languages were recognized, and even used, in the newspapers, this was framed as either a pathway to Christianity, some form of entertainment, or-especially in the work of Wilsonas salvage. She has a strong message to settler Canada's often clumsy attempts at redress (esp. CBC) as well as praise for positive developments such a Simon Fraser University's Kwi Awt Stelmexw Squamish Language program. She also discusses the then yet to be passed Act Respecting Indigenous Languages. The good news is that it did pass in June 2019, with its mandate to "support the efforts of Indigenous peoples to reclaim, revitalize, maintain and strengthen Indigenous languages" (Government of Canada, 2019, p. 2). As one commentator points out, the challenge is to move beyond linguistic interest and the training of indigenous language teachers, toward "increas[ing] the number of homes speaking the language as their primary mode of communication, and raising their children with intergenerational language support" (Vowel as cited in Griffith, p. 245).

As a communication scholar, Jane Griffith uses other concepts and terms than those that underpin discourse and genre studies. However, drawing from the ideas recently laid out in this journal's pages, she could be an example of what Sune Auken (2020) describes as a "plethora of researchers actually working with genres, even though they do not conceive of their work as genre research" ( $p$. 167). This book-length study of early Indian boarding school newspapers, therefore, can be thought of as genre research without being "genre research proper" (p. 163), and indeed contribute meaningfully to discourse and genre studies. For example, genre researchers and students whose work overlaps with settler colonial studies could wisely attend to Griffith's cautions, as a white scholar, to expose the workings of colonial power without voyeurism, exploitation, or absolution seeking. And for educators of non-Indigenous students in our courses who might respond to Indigenous content we provide to develop their own research questions, her approach to reading the archive and her reflections on her research process would be useful.

Griffith is often left to speculate as to the intentions of her now long-deceased authors to suggest alternatives to the surface reporting in Indian boarding school newspapers. She asks us to imagine, for example, when a chief's visits to the school is reported in newspapers, what aspects of his visit go unreported (p. 185). Elders and other family members, we are reminded, might often want to see for themselves the condition of the schools to ensure their children's adequate care. If Griffith needs to speculate on these and other matters, it is because of the need to witness and address the role of language in the contemporary framing of residential schools in Canada. This speculation could likely 
Volume 31, 2021

http://journals.sfu.ca/dwr

be supported by a genre approach that casts language use as a matter of shared genre knowledge among those key participants who have genre-sanctioned speaking rights. The attribution of intentions is often a problem but for readers of $D W / R$ treating these newspapers as discourse and as genre renders this question moot.

\section{References}

Auken, S. (2020). On genre as social action, uptake, and modest grand theory. Canadian Journal for Studies in Discourse and Writing/Rédactologie, 30, 105-132.

Government of Canada. Indigenous Languages Act. S.C. 2019, c. 23 https://lawslois.justice.gc.ca/eng/acts/I-7.85/page-1.html 